https://doi.org/10.18485/bogoljub_stankovic.2018.ch15

811.16'366.596

\author{
ЛюДМИЛА ПОПОВИЧ* \\ Белградский университет \\ Филологический факультет \\ Кафедра славистики
}

\title{
ТЕМПОРАЛЬНЫЕ ЗНАЧЕНИЯ СЕРБСКОГО ПОТЕНЦИАЛА І И СПОСОБЫ ИХ ПЕРЕДАЧИ В ДРУГИХ СЛАВЯНСКИХ ЯЗЫКАХ"
}

В данной статье рассматривается факт временного употребления потециала I в современном сербском языке для обозначения единичных неповторяющихся действий. Анализ данного типа конструкций в сербском языке в сравнении с другими славянскими языками показал, что потенциал в сочетании с союзом ga и обстоятельством времени входит в особый вид сложных предложений с сочинительно-подчинительной связью,

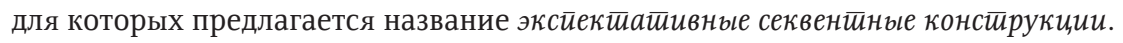

Ключевые слова: экспектативная конструкция, потенциал I, союз да, славянские языки

Lyudmila Popović

\section{TEMPORAL MEANINGS OF THE SERBIAN CONDITIONAL MOOD (POTENCIJAL I) AND THEIR EQUIVALENTS IN OTHER SLAVIC LANGUAGES}

This article discusses the temporal meaning of Potential I that is used in modern Serbian language to describe single non-recurring situations in the past in sequent constructions. Analysis of this type of structures in Serbian language compared to other Slavic languages has shown that Potential I, combined with the conjunction $D A$ and a lexical temporal marker, is a part of a special kind of complex taxis sentences, for which I propose name Expectative Sequent Construction.

Key words: expectative sequent construction, Potential I, conjunction DA, Slavic languages

·ljudmila.popovic@fil.bg.ac.rs

.. Данная работа выполнена в рамках научно-исследовательского проекта 178021 Министерства просвещения, науки и технологического развития Республики Сербия. 


\section{0 Потенциал I в сербском языке}

Потенциал I в сербском языке сочетает в себе модальные и темпоральные значения, для которых общим является нереференциальное употребление, т.е. несоотносимость с конкретной реальной ситуацией, так как временное употребление данного способа связано с передачей повторяемых действий в прошлом (Стевановић 1974: 710-720; Танасић 2005: 457-463; Пипер, Клајн 2013: 406-407). Исследователи в свое время обратили внимание на временную несовместимость повторяемого прошедшего действия, которое выражается потенциалом I, с моментом речи (Ивић 1995: 44), в отличие от повторяемых действий, выраженных перфектом НСВ, ср.:

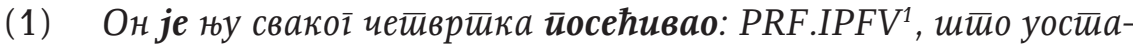
лом и gан-gанас чини.

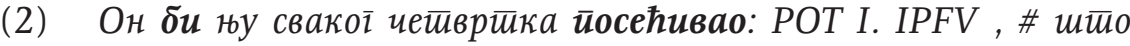
уостиалом и gан-gанас иини.

Необходимо также подчеркнуть, что потенциалом I выражается хабитуальность, проявляющая себя в особых условиях, которые содержаны в локативных либо темпоральных обстоятельствах. Речь идет о так называемой „хабитуальной кондициональности” (Пипер 1998), когда действие повторяется только при соблюдениии определенных условий, ср.:

(3) Тої ирролећа бих йлакала: РОТ I. IPFV йосле свакої нашеі̄ сусpēüa.

(4) ${ }^{*}$ Тог̆ ирролећа йлакала бих: РОТ I. IPFV .

Факт того, что действие, описанное в примере (3) повторялось в прошлом только при возникновении определенного условия, каковым в данном примере является встреча (сусрей), объясняет употребление неиндикативного условного наклонения в подобном контексте. В данном случае имеет место так называемая реальная кондициональностиь (Пипер 1998: 46).

Однако для сербского потенциала характерно и темпоральное употребление, не освещенное в грамматиках серб́ского языка, - он может передавать единичное неповторяющееся действие, соотносимое с конкретной ситуацией в прошлом:

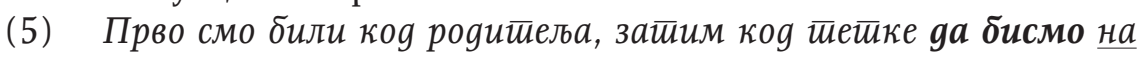
крају ойишли: РОT I. PFV коg йријайељьа (Разг.).

${ }^{1}$ Здесь и далее в тексте используются следующие условные обозначения: POT I - потенциал I, PFV - соверш. вид, IPFV - несоверш. вид, IMPF - имперфект, PRS - презенс, PRF - перфект, PPRF - плюсквамперфект, IMPF - имперфект. 
Речь идет об особом типе таксисных конструкций, в которых ситуация, описываемая потенциалом I, является логическим продолжением предшествующей ей ситуации либо противопоставляется ей. Потенциал в данном типе предложений может быть как несовершенного, так и совершенного видов, ср.:

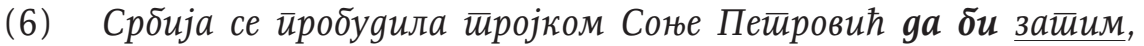

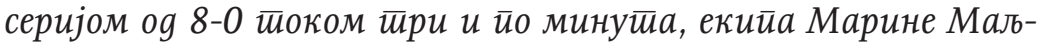
ковић йоново воguла: POT I. IPFV, 15-14 (Кошаркашки савез Србије, 13.06.2015).

(7) Накрајуматиурскої ӥлеса извеgеноі̄ у четиири слике, краљевачки

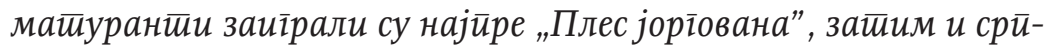
ско коло, gа би на Трі̄у насйавили: РОТ I. IPFV gа се забављају уз хийове забавне и нарояне музике (Танјуг 22.05.2015).

Обязательным элементом таких предложений является союз ДА, а

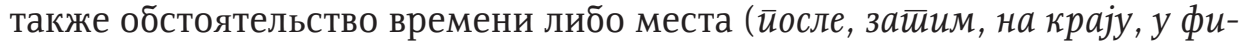

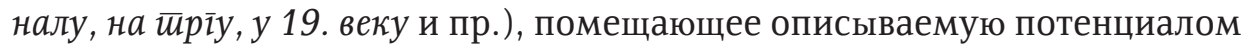
ситуацию в конец секвентной конструкции.

(8) Њихова жижа јеgно време бива Пећ и юена йайријариија,

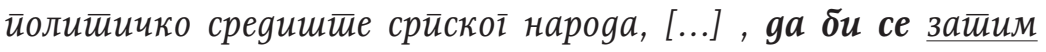
књижевно среgишие йомерило: РОТ I. PFV далеко на север, у Сремске Карловще [...] (М. Павић, Барок).

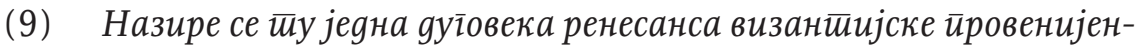

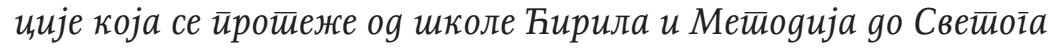

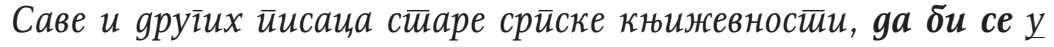

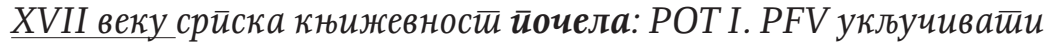
у зайаgноевройски барок (М. Павић, Барок).

Если из таких конструкций изъять обстоятельство времени (либо места, при наличии метонимии), то они могут превратиться в сложноподчиненные предложения с придаточным цели, ср.

(10) Завршио је їимназију gа би затичм уйисао: РОT I. РFV факул$\bar{u} e \bar{u}$.

(11) Завриио је і̄имназију gа би уйисао: РОТ I. PFV факулйей.

В некоторых случаях, вместо ожидаемого обстоятельства, на завершение ряда последовательных ситуаций может указывать семантика фазового глагола:

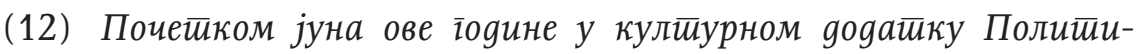

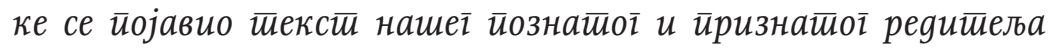
Алексанgра Манgића йоg називом Моја ирква, иунами и ја у коме, најире, ойисује скорашюи сусрети са својим йарохијским 


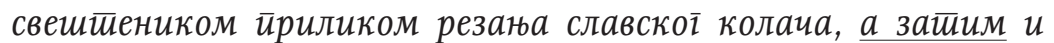
низ својих размишљана о местиу и начину делована Цркве и йојеgиних юених иланова у савременом срйском gрушйву gа би завричо: РОТ I. PFV речима йошйована иррема блаженойочившем йайријарху Павлу коїа узима као йример и узор... (www.eparhija-sumadijska.org.rs)

Обращает на себя внимание тот факт, что другие глаголы в данном типе предложения могут быть в форме исторического настоящего, тем не менее потенциал после союза ДА закрывает секвентную конструкцию. Если после потенциала в секвентной конструкции и употребляются другие глаголы, то только в форме перфекта, см. (14).

(13) Поілеgајйе како овај уснули йас најӣре йочиње: PRS.IPFV ga

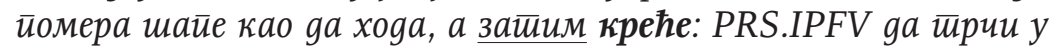
сну, gа би се на крају йробуguо: POT I. PFV и оg све йе збуюеносй кренуо ка зияу и ygapuо у юеі̄a йлавом! (Радио Пингвин)

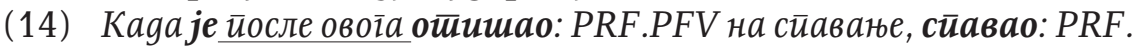

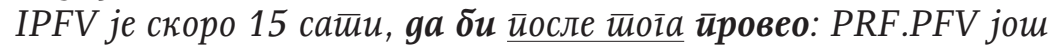
23 сайа буgан, иекајући ноћ, а затичм је сйавао: PRF.IPFV jou 10 u $\bar{u} о$ cāuu (www.wikipedija)

Данный тип конструкций представляет собой сравнительно новое явление в сербском языке. Например, в корпусе, содержащем десятилетнюю подписку ежемесячной газеты „Београдске општинске новине” (1931-1941) нам не удалось отыскать ни одного примера секвентной конструкции с потенциалом и союзом ДА, в то время как в современном языке они часто встречаются в языке прессы. Вместо сложных таксисных конструкций, содержащих потенциал, сербские журналисты и писатели в первой половине 20-го века преимущественно употребляют простые предложения с соответствующими временными обстоятельствами либо сложносочиненные предложения, а таксис выражается на уровне текста, ср.:

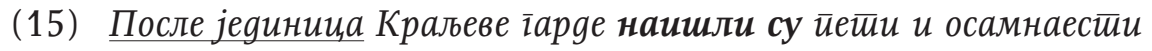
иукк [...]. Иза иетешаgије слеgовао је gруі̄и арйилеријски йук. Дефиле је завриен болничком чейом, ауйо-командом и байаљо-

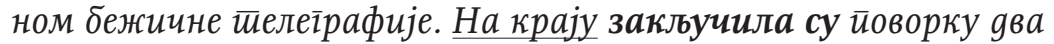
оклойлена авйомобила (Београдске општинске новине, септембар 1932: 611-612).

(16) Дефиле је иррошао иенйралним іраяским улии,ама, йореg Новосаяскої сајма, кроз насеље Лиман, йреко мосйа „Вараяинска gуїа" gа би на крају биичклистич освојили: РОT I. PFV и Пей-

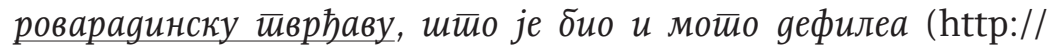
europa.rs). 
В приведенных примерах, см. (15-16), изображены приблизительно одинаковые ситуации, описываемые очевидцами событий. В первом примере, см. (15), ситуация описывается с помощью четырех простых предложений, каждое из которых содержит ориентир темпорального порядка и глагол фазисной либо таксисной семантики (наишли, слеgовао, завршен, заклуиила су), указывающий на секвентную связь между предложениями, в то время как во втором примере, см. (16), темпоральная цепочка моделируется имплицитно, путем описания маршрута, а конструкция ДА + потенциал с обстоятельством на крају подчеркивает секвентную связь.

Со второй половины 20-го века сочетание ДА + потенциал в секвентных конструкциях становится привычным во всех функциональных стилях, хотя грамматики ее не регистрируют:

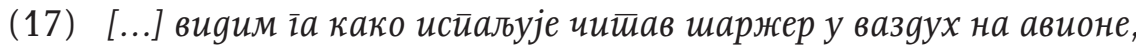

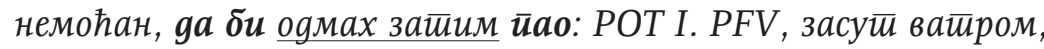
земљом и шрайнелом [...] (Данило Киш, Гробнии, за Бориса Давияовича, 1976)

(18) Коначно йламичии захватее све листиове, лизну иреко корииа извијајући их и йойамљујући, сйајајући се у ... йламен који сукља и скаче високо, gа би затим йолако йочео: РОТ I. PFV

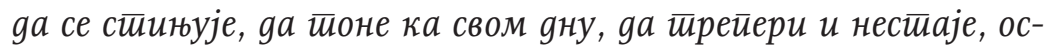
йављајући иза себе жар и йейео (Александар Тишма, уйойреба човека, 1976).

(19) Маgа сасииављена ирема немачком обрасиу, франиуска ірама-

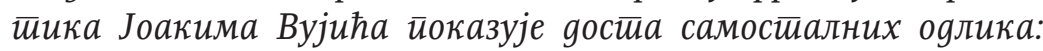
она gаје обавештеньа о Карађорђу и о срйској револуиији, уз

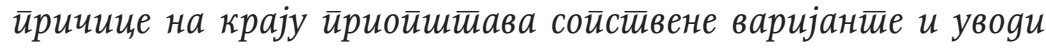
нешйо хебрејских речи gа би на крају носила: РОT I. IPFV

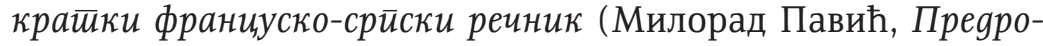
манйизам, ИСК 1991).

(20) Арсенал увреgа йрајао је неко време gа би у јеgном ииренуйку, сасвим неочекивано, у Мирољубовој свесии иошло: РОТ I. PFV

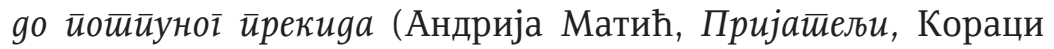
7-8, 2009).

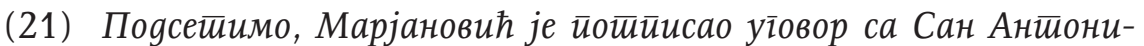
ом након шито је иррошао лекарске ирреіллеgе у Милану, gа би се зайим у стираним меgијима йојавио: РОT I. PFV иниеервју йомоћноі йренера Црвене Звезgе Велибора Раgовића, који је изјавио gа је Марјановић иірао „са сломљеним сйойалом" у финалу иллеци-офа АБА лиїе (www.sportskacentrala.com). 


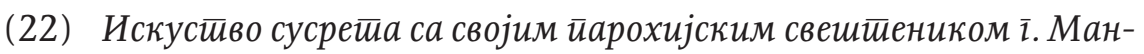
gић изражава на слеgећи начин: "Та йојава која као брзи воз иробрбља молитиве, онgа сеgне и као на феgер навијен издекламује своје ілууиостии намењене йасииви коју оииілеяно вияи као

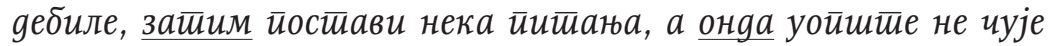

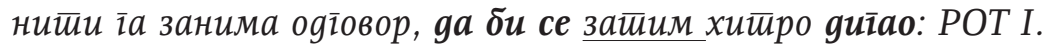
PFV, узео свој хонорар и о эмаїлио" (www.eparhija-sumadijska. org.rs).

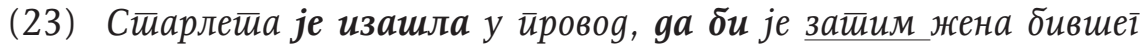
момка найала: POT I. PFV (http://tracara.com)

Темпоральная конденсированность данных конструкций делает их удобными для использования в хрониках и исторических описаниях, в которых они лишены экспрессивности:

(24) Bolesnik je dugo i teško umirao, da bi se na kraju Turska svela: POT I. PFV na teritoriju srazmernu njenoj moći (www.emins.org/sr).

(25) Оgмах се састиаје са Карађорђем, вођама усшанка, илановима

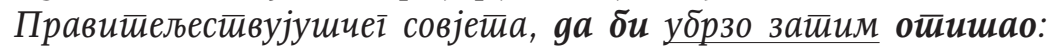
РОT I. PFV у gийломайску мисију у Букурешй и ииамо био оgликован злайним крсииом рускоі и,ара (www.skoladositejklupci. edu.rs).

(26) Срезневски је с несманеном раgозналошћу йрайио раg Вуков. Приказом је йройрайио њеі̄ов Рјечник (1852) [22] ga би убрзо

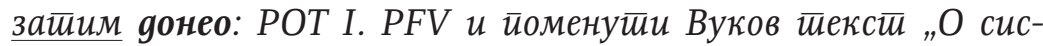

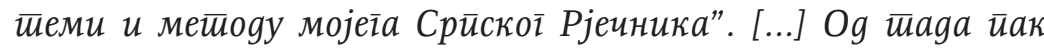

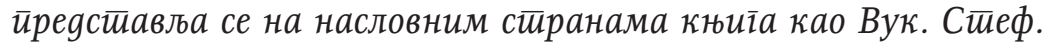
Караиић (Јаgранин из Тршића, а оg стиарине Дробнак из Пейниц, ), ga би убрзо речи у заіраgама оgбаиио: РОТ I. РFV (Голуб Добрашиновић, Вуков животопис од И. И. Срезњевског).

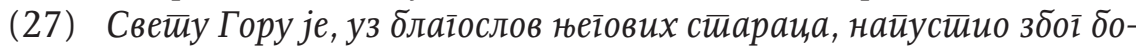

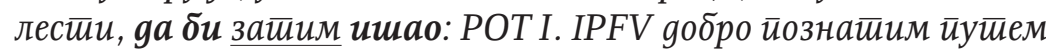
gок на крају, раяи мира и сйокојстива, није отишио у Милеси, у Малакаси, īge је йоgиі̄aо свој чувени манасйир (Светосавље).

\section{0 Прошлое неактуального мира}

На взаимосвязь условного наклонения и прошедшеих времен изъявительного наклонения в свое время обратил внимание еще А.А. Потебня. Ссылаясь на данные из другух индоевропейских языков, в частности, на санскрит, в котором „сослагательное имеет аугмент (знак прошедшего времени)”, а также на сербский и болгарский, в котором „условное значение получают и другие прошедшие времена изъявительного наклоне- 
ния", ученый делает вывод о существовании „преходящего условного”, т.е. имперфекта, способного выражать условное значение, при котором позже развивается частица би (Потебня 1958: 268-269). Данный вывод А.Потебня подтверждает следующим серб́скими примерами:

(28) Ал' с' волија: ІМРF Пивљанина Баја, ал' Турчина Куну Хасан-аїy?"

Но іовори Анђа Иванова:

"Е волијах: IMРF Пивљанина Баја" (Бајова свадба)

(29) „Мајко моја, gуі̄o јаgна била!

Волијах: IMPF би Мирковића Вука

само іола, у кошуљи йанкој,

неі̄o йашу, моїа вјерника,

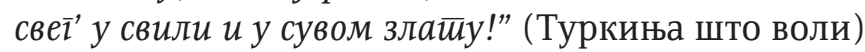

Необходимо, однако, обратить внимание на факт того, что в данном случае выражается не условность, а оптативность (волијах/ волијах би 'я б желала'). Условное же значение, проектируемое в прошлое, в сербском языке не может быть выражено формой потенциала, а вместо этого употребляется форма перфекта и условные союзы $а$ ко, уколико 'если':

(30) Ако је gобио: PRF.PFV јуче моје йисмо, сиі̄урно ми је већ оgі̄oворио: $P R F . P F V$.

Употребление потенциала в приведенном примере возможно только при вопросительной интонации, т.е. при наличии модальности, переводящей условность из реального временного плана в неактуальный мир:

(31) Шииа мислиш? Ако би gобио: РОТ I.PFV јуче моје йисмо, сиіуурно би ми већ оgі̄oворио: POT I. PFV?

Если потенциал указывает на временной план прошлого, то, как уже было сказано, описывает повторяющееся действие. Вместо условного союза ако в таком случае употребляется темпоральный союз $\mathrm{kag}(\overline{\mathrm{i}} \mathrm{og})$ :

(32) Kag (īog) би goбио: POT I.PFV йисмо, оgі̄оворио би: POT I.PFV ми.

Таким образом, потенциальное условие, совмещенное с планом прошлого, превращается в реальное, то есть имеет место уже упомянутая реальная кондициональность, „при которой не возникает пресуппозиция о возможности отсутствия реализации ситуации в главной части" (Пипер 1998: 46). Условие в прошлом и настоящем может быть реальным либо ирреальным (контрфактическим) ${ }^{2}$, условие, соотноси-

${ }^{2}$ В сербском языке контрфактичность в настоящем и прошлом выражается разными конструкциями, в русском же языке данные различия нивелируются, если их не 
мое с планом будущего, может быть и потенциальным (см. Станојчић, Поповић 1997: 313). Тијана Ашић и Веран Станоевич (Ашић, Станојевић 2009), сравнивая темпоральные значения сербского потенциала и французского кондиционала, приходят к выводу о том, что отсутствие возможности выразить языковыми средствами потенциальное условие в прошлом создает предпосылку для одновременного использования данных форм в модальном и темпоральном значениях, так как в обоих случаях речь идет о хронологическом взаимоотношении ситуаций в реальном мире (указание на будущее в прошлом) либо в одном из возможных миров. Во французском языке такая функция кондиционала выделена в качестве указания на буgущее неакйуальнойо мира (Vetters 2001). Если способность французского кондиционала совмещать модальные и темпоральные функции (см. Dendal, Tasimovski 2001, Haillet 2002, Ашић, Станојевић 2009), объясняется формальными особенностями данного наклонения/временой формы (futur du passé), формирующегося от основы будущего времени путем добавления к ней окончаний имперфекта, то частица $\delta ы$, восходящая к форме аориста (см. об этом подробнее в Сичинава 2004), связывает славянский потенциал/кондиционал с йрошльм неакйуальноі̄о мира. Именно об этом и писал А.А.Потебня: «Весьма вероятно, что основание перехода прошедшего времени изъявительного наклонения к значению условности, или tertium comparationis между прошедшими временами изъявит. накл. и условностью, и даже вообще идеальными наклонениями, каковы условное, сослагательное, желательное, состоит в том, что как идеальные наклонения изображают события существующими только в мысли, так и прошедшее может рассматриваться 'со своей негативной стороны, как отрицание действительного присутствия (наличности) явления' (Bopp, Vergl.Gr. 520), в том смысле, что если явление было, то, стало быть, его уже нет» (Потебня 1958: 268). Исходя из данного толкования, темпоральные и модальные употребления сербского потенциала, описанные в сербских и хорватс-

выразить лексически, ср. а) контрфактичность в настоящем - конструкция $g a+$ презенс HCB в протасисе: Да знам: PRS.IPFV, рекао бих ти. 'Если б я знал, то сказал бы тебе'; а) контрфактичность в прошлом - конструкция $g a+$ прош. время НСВ в протасисе: Да сам

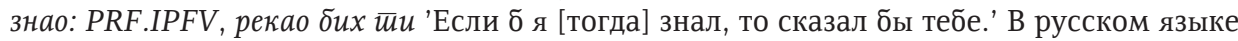
в протасисе обоих типов конструкций употребляется условный союз и форма кондиционала, а на контрфактичность в прошлом указывает соответствующее обстоятельство времени. Возможность выразить контрфактичность в прошлом грамматическими средствами находим в тех языках, где в протасисе можно употребить условное наклонение плюсквамперфекта, например, в украинском: а) контрфактичность в настоящем - конструкция якби + прош. время в протасисе: 'кби я знав: PRF.IPFV, сказав би тоб'. 'Если б я знал, то сказал бы тебе'; б) контрфактичность в прошлом - конструкция якби + условное наклонение плюсквамперфекта в протасисе 'кби я був знав: PPRF.IPFV, сказав би тоб'. 'Если б я знал [тогда], то сказал бы тебе', (см. об этом также в Поповић 2012). 
ких грамматиках (Стевановић 1974: 710-720; Танасић 2005: 457-463; Пипер, Клајн 2013: 406-407), можем считать результом мысленного перемещения действия, обозначенного данной временной формой, в один из неактуальных миров - воображаемый мир либо мир неактуального прошлого, прекратившего свое существование. Именно данным фактом можем объяснить невозможность пересечения временнного плана, обозначенного потенциалом с моментом речи, о котором шла речь ранее (Ивић 1995).

Однако такое толкование семантики потенциала, совершенно приемлемое для описания его темпоральной функции при выражении повторяемых действий в прошлом, не проливает свет на возможность использования данной формы для описания единичных неповторяющихся действий в прошлом. По-видимому, в данном случае необходимо исходить не из значения глагольной формы, а из семантики конструкции, в которой она употребляется.

\section{0 Телические конструкции}

Предложения, в которых конструкция ДА+потенциал употребляется для обозначения единичного совершившегося факта, т.е. во временном значении, по форме напоминают сложноподчиненные предложения с придаточным цели, что дает формальный повод рассматривать их в качестве псевдоцелевых предложений. Для подобных предложений в английском языке предложен термин телические предложения (Telic Clauses) (Whelpton 2001):

(33) She survived the Holocaust, to spend the rest of her life fighting against prejudice and discrimination.

'Она је преживела Холокост да би затим провела остатак свог живота борећи се против предрасуда и дискриминације.'

(34) John hung his coat up, only to realize that he had to go out again.. 'Џон је окачио капут да би затим схватио да поново мора изаћи'.

Данный тип предложений (Telic Clauses) отличается от каузативных конструкций (Rationale Clauses), в которых выраженное инфинитивом действие каузировано намерением агенса, см. (35), и собственно целевых (Purpose Clauses), в которых действие главной части мотивируется семантикой объекта, см. (36), (Whelpton 2001: 314).

(35) John hung up his coat (in order) to have his hands free.

(36) John designed the stool [for people with back problems to sit on]. ${ }^{3}$

\footnotetext{
${ }^{3}$ Приведенные примеры (32-36) взяты из (Whelpton 2001: 313-314).
} 
Как показано в Whelpton 2001, в телических предложениях (Telic Clauses), отличных от рациональных (Rationale Clauses) и собственно целевых (Purpose Clauses), части сложной синтаксической конструкции связываются внутренней связью, вытекающей из семантики глагола в ГЧ, склоняющей говорящего и слушающего задуматься над тем, как будет протекать в дальнейшем ход событий. Если развитие ситуации подтверждает ожидания, заснованные на прагматическом и культурном знании о мире говорящего и слушающего, инфинитив выражает результирующее событие ${ }^{4}$ см. (33), если же событие, выраженное инфинитивом, противоречит ожиданиям говорящего, телическая конструкция носит адверсативный характер, см. (34). Данный подход помогает рассматривать результирующие (псевдоцелевые) и адверсативные (антицелевые) телические конструкции в качестве двух сторон одной медали (Whelpton 2001: 335), так как оба типа указывают на неуверенность говорящего в том, каким образом ситуация может развиваться в будущем - исполнит ли она его ожидания или нет. Если говорящий склоняется к мнению, что будущая ситуация станет логическим итогом предыдущей, имеет место результирующая теличность, если же он считает, что будущая ситуация противоречит логике предыдущей, реализуется адверсативная теличность ${ }^{5}$.

Общей чертой телических предложений является наличие внешнего оператора-предиката (telos), который указывает на факт существования секвентной связи между ситуациями. Переход одной ситуации в другую, создает определенный горизонт ожидания, условленный знаниями говорящего о мире. Итоговая ситуация удовлетворяет либо не удовлетворяет данным ожиданиям, но никоим образом ими не детерминирована ${ }^{6}$.

Принимаем мнение Велптона о том, что отличием телических конструкций является внешний оператор-предикат telos, моделирующий семантику конструкции в направлении предвосхищения итога исходной ситуации. Для нас в приведенном определении телических конс-

${ }^{4}$ The resolutional Telic Clauses thus resolve uncertainties which are raised in the context of our world knowledge by the event described by the main verb (Whelpton 2001: 334).

${ }^{5}$ Viewing the interpretation of the Telic Clauses in this way allows us to see the resolutional and adversative Telic Clauses as sides of the same coin, because the adversative Telic Clauses also resolve our uncertainties about how the main event 'turns out', it simply indicates that the resolution was a negative one, one that does not fulfil our expectations. This is part of the reason why adversative Telic Clauses are easier to formulate. An adversative Telic Clause will be allowed with 'predictable' sequences of events, precisely because it violates the predictability of the sequence (Whelpton 2001: 334).

6 "Telos $\left(<\mathrm{e}^{1}, \mathrm{e}^{2}>\right)$ there is a transition from $\mathrm{e}^{1}$ to $\mathrm{e}^{2}$, where $\mathrm{e}^{2}$ supplies a resolution of expectations aroused by $\mathrm{e}^{1}$ and that resolution is not pre-determined by those expectations" (Whelpton 2001: 335). 
трукций, см. (Whelpton 2001: 335), ключевым словом является именно „ожидание”. Имеется в виду ожидание говорящим того, каким образом ситуация может развиваться в будущем. В связи с этим, а также при-

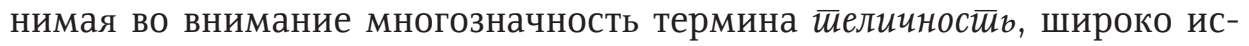
пользуемого, в частности, в аспектологии, предлагаем другой термин экспектативность, который, по нашему мнению, лучше отражает семантику данного типа конструкций в славянских языках ${ }^{7}$

\section{0 Многоликость конструкций с союзом ДА}

Большинство исследователей соглашается в том, что союз ga в славянских языках, в зависимости от ареала, употребляется в качестве сочинительного и подчинительного союза либо, будучи частицей, выполняет модальные функции (Maretić 1887: 132-134; Bauer 1972: 91-95; Стеценко 1972: 183; Грковић Мејџор 2004; Štrkalj Despot 2012). В данных исследованиях привлекает внимание предположение Ясмины Гркович Мейджор о том, что многоликую судьбу слова gа в разных славян-

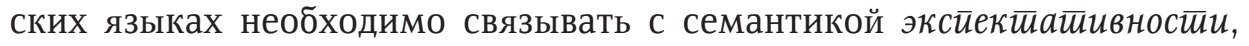
присущей ему изначально. Ссылаясь на (Beekes 1995), Ясмина Гркович Мейджор выводит происхождение данной частицы от аблативной формы ${ }^{*} \mathrm{~d} /(\mathrm{t}) \mathrm{o} \mathrm{d}$, которая, будучи окончанием индоевропейского императива II, указывала на то, что действие должно совершиться в ближайшем будущем ${ }^{8}$. Исходя из этого, выводится инвариантное значение частицы ga, определенное как экспектативность (Грковић Мејџор 2004: 186), т.е. указание на действие, которое должно произойти в отношении определенного момента либо его осуществление ожидаемо.

Именно данное инвариантное значение ga, состоящее в указании на начальную точку отсчета, дает возможность развиться всем другим семантико-синтаксическим функциям этого слова. Инвариантное экспектативное значение служит основой для употребления союза ga в сек-

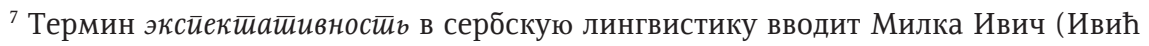
1970 ) при описании конструкций с глаголами проспективной семантики, присоединяющих на позиции внешнего предиката сентециальное дополнение, стандартно выраженное в сербском языке конструкцией ДА + наст. вр. Милка Ивич говорит о том, что экспектативность в таком случае можно считать сентенциональным адвербиалом, который сигнализирует, что действие, обозначенное глаголом на позиции внутреннего предиката ожидается, исходя из семантики глагола-внешнего предиката. Таким образом, для предложения Желео сам gа засиим предлагается описание $\mathrm{S}=\mathrm{S}_{1}+\mathrm{Exp}+\mathrm{S}_{2}$,желео сам + ga буgе

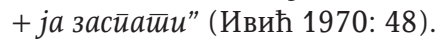

8 „Могуће је, међутим, да се овде ради о аблативном облику *d/(t)ôd, истој форми која се јавља као наставак у индоевропском императиву II, указујући на то да радња треба да се догоди у блиској будућности (Beekes 1995: 248)" (Грковић Мејџор 2004: 185). 
вентных конструкциях, так как он сохраняет в своей внутренней форме значение начальной точки отсчета („от данного момента и далее” > „после того” > „и"). При указании на темпоральный порядок ситуаций данный союз зачастую выражает противительные отношения. С другой стороны, указание на будущее действие открывает возможность для развития у слова ga модальной, оптативной либо субъюнктивной, семантики, так как связь между категориями постериорности и субъюнктива универсальна ${ }^{9}$.

По замечанию исследователей, противительная функция союза ga известна в восточнославянских и южнославянских языках, в западнославянских же данный союз весьма редко встречается (Maretić 1887:132-134). Противительное ga типично для древнерусского языка, впоследствии оно закрепляется в русском, где существует и сегодня (Стеценко 1972: 183). Исследователи отмечают, что в южнославянских языках данный союз/частица выполнял противительную функцию на определенном этапе в прошлом, в частности, в серббком и хорватском языках (Грковић Mejџор 2004; Štrkalj Despot 2012), но она замирает, уступая со временем место конъюнктивной, субъюнктивной и модальной функциям.

Наше исследование, однако, показывает, что в сочетании с потенциалом, обозначающим единичное неповторяющееся действие, у союза ga в современных южнославянских языках, в частности, в серб́ском, хорватском и словенском, актуализируется экспектативный момент его семантики, позволяющий ему быть задействованным в соответствующих предложениях. На существование подобных конструкций в хорватском языке обратил внимание Иво Прањкович: „Ima međutim jedan tip nezavisnosloženih rečenica, koje Musić u svojoj raspravi ne spominje, a ne spominju ih uglavnom ni gramatike hrvatskoga standardnoga jezika, u kojima je riječ $d a$ još uvijek relativno česta u službi konjunktora (tj. veznika nezavisnosloženih rečenica), npr. Puno je pričao, prijetio, da bi zatim naglo nestao. Štoviše, da je tu u službi svojevrsnoga suprotno-sastavnog veznika, za koju

9 „Овакво објашњење, по којем је ga аблативног порекла имало примарно значење означавања тачке поласка („од тога надаље”) открива инваријантно значење дате партикуле којим се може објаснити њена употреба и синтаксичко-семантичке функције.

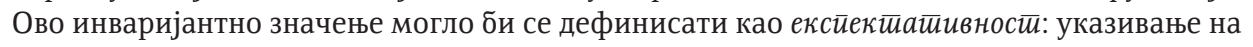
радњу која тек треба да се догоди у односу на одређени тренутак или чије се извршење очекује (Ивић 1970: 48). Развој основног значења може се, с једне стране, кретати ка адјунктивној, те паратаксичкој употреби $g a$, које указује на основни темпорални след догађаја („од тога надаље” > „после тога” > „и”). С друге стране, упућивање на будућу радњу отвара могућност развоја модалног ga оптативне или субјунктивне семантике, с обзиром на концептуалну везу категорија будућности и модалности" (Грковић Мејџор 2004: 186). 
(službu) i Musić tvrdi da je za koordinirano da nekad bila tipična. I za takvo bi se da međutim moglo ustvrditi da je negdje između konjunktora i subjunktora, sudeći bar prema tome da uza nj obvezatno dolazi kondicional, koji cijelu takvu konstrukciju čini na neki način tipiziranom" (Pranjković 2008:506). Необходимо также отметить, что некоторые актуальные пособия по культуре хорватской речи рекомендуют не употреблять такие конструкции, а предпочитать им сложносочиненные предложения ${ }^{10}$. Потенциал I употребляется в данном значении и в словенском языке, хотя конструкции такого типа не считаются типичными для этого языка, а вместо него рекомендуется употреблять соответствующий сочинительный союз: „Raba pogojnika v zvezah kot Olimpija je premagala Partizana, da bi nato izgubila s popolnoma slabim moštvom je neslovenska; prav: ...nato pa izgubila" (Toporišič 1976: 332). Как будет показано ниже, ситуация на практике выглядит несколько иначе. При потенциале ga может и сегодня выступать в серббком, хорватском и словенском языках в качестве сочинительного союза.

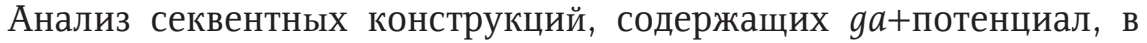
сербском языке показывает, что можно выделить четыре типа предложений, в которых союз gа выполняет разные функции, соотносимые с разными типами сочинительных отношений. Собранные примеры показывают, что в сербском языке можно выделить четыре функции союза ga в исследуемых конструкциях - подытоживающую, выделительную, сопоставительную и противительную. Примеры, иллюстрирующие все четыре функции, были предложены лингвистам, носителям разных славянских языков, для перевода на их родной язык ${ }^{11}$. Результаты данного эксперимента представлены ниже.

${ }^{10}$ Приводим один из примеров таких лингвистических советов: „Konstrukcija da bi u prirodnom hrvatskom jeziku uvijek znači namjeru, a ne nekakvu buduću prošlost (kao $\mathrm{u}$ engleskom Future in the past), jer takvo glagolsko vrijeme u našem prirodnom jeziku ne postoji. Kao na primjer u standardnoj rečenici: Oženio je prekrasnu djevojku, da bi ubrzo zatim poginuo u prometnoj nesreći. Na prirodnom jeziku bi to značilo da se oženio s namjerom da pogine, što je apsurd, a uvođenje novih glagolskih vremena, kojih u narodnom jeziku nema, samo kvari jezik. Na narodnom jeziku bi prednja rečenica glasila: Oženio je prekrasnu djevojku, ali je ubrzo zatim poginuo u prometnoj nesreći" (hr.wikipedia.org).

${ }^{11}$ Искренне благодарю уважаемых коллег Зузану Тополиньску, Соню Миленковску, Андрею Желе, Евгения Пащенка, Йосипа Ралашича, Яромира Линду, Светлу Рускову, Микиту Супрунчука, Виолу Козею, Стефану Паунович Родич и Зденека Андрле за участие в эксперименте и указанную мне помощь при переводе примеров. Выражаю также благодарность уважаемым коллегам Виктору Самуиловичу Храковскому и Предрагу Пиперу за содержательные комментарии к статье. 
4.1 Подытоживающая функция союза ga в конструкциях с потенциалом

В данном типе конструкций вторая часть, присоединяемая союзом ga, является ожияаемым ийоі̄ом первой части. Экспектативный момент семантики союза ga получает свое логическое подтверждение на уровне синтаксических отношений.

(37) (серб.) Србија се йробуgила йројком Союе Пейровић gа би за-

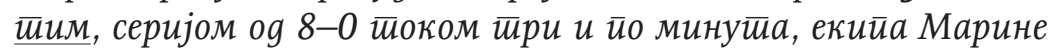
Маљковић ионово воgила 15-14

(38) (хорв.) Srbija se probudila tricom Sonje Petrović da bi zatim, serijom od 8-0 kroz tri i pol minute, ekipa Marine Maljković ponovno vodila 15-14.

(39) (словен.) Srbija se je zbudila s trojko Sonje Petrović, da je potem lahko v teku treh in pol minut s serijo 8-0 ekipa Marine Maljković znova vodila 15-14.

(40) (мак.) Србија се разбуgи со йројкайа на Соња Пейровиќ, за

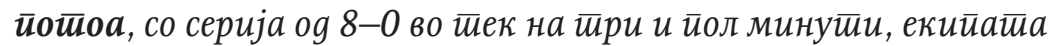
на Марина Маљковиќ йовтиорно gа воgи со 15-14.

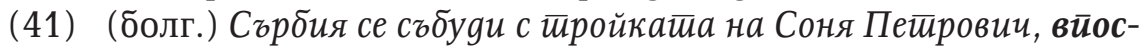

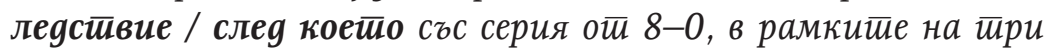
минуйи и йоловина, на екийа на Марина Малькович ойново gовеge go 15-14.

(42) (пол.) Serbia obudziła się po trójce Sonji Petrović, i następnie dzięki serii rzutów 8:0, w ciagu trzy i pót minuty, ekipa Mariny Maljković ponownie prowadziła rezultatem 15:14.

(43) (чеш.) Srbsko se probudilo trojkou Sonji Petrovićové, načež se sérii (hodů s výsledkem) 8:0 během tř́ a pưl minut družstvo Mariny Maljkovićové znovu dostalo do vedení (výsledkem) 15:14.

(44) (слов.) Srbsko zobudila trojka Sonje Petrovičovej a potom, vdaka sérii ôsmich bodov behom tri a pol minút, družstvo Mariny Maljkovičovej znovu vyhrávalo 15:14.

(45) (рус.) Сербия проснулась после трехочкового броска Сони Петрович, и после этого, в результате серии бросков 8:0 на протянении трех с половиной минут, команда Марины Малькович снова вырваласв впереg 15:14.

(46) (укр.) Сербія прокинулась після триочкового Соні Петрович, $\boldsymbol{i}$ після и,ього, в результаті серії кияків 8:0 протягом трьох з половинию хвилин, команда Марини Малькович знову повела 15:14.

(47) (бел.) Сербія прачнулася аg трохачковага кіgка Соні Петравіи, а потым пасля серыі з 8-0 на праиягу трох з паловай хвілін каманда Марыны Малькавіч зноў павяла $з$ лікам 15:14. 
Функция союза ga в данных примерах может быть условно названа подытоживающей. Она реализуется в конструкциях, имеющих результирующее толкование (a resolutional reading Whelpton 2004: 324). Употребление потенциала после союза ga в сербском и хорватском языках, см. (37-38) указывает на факт помещения итоговой ситуации в неактуальный мир. Говорящий становится на конечную черту события в прошлом в ожидании будущего, являющегося, исходя из его знаний о мире, возможным итогом свершившегося. Контраст между осуществившимся и возможным передается с помощью сочетания перфекта в первой части, указывающего на актуальный мир ситуации $\mathrm{S}_{1}$, и потенциала, ассоциируемого с экспектативностью ситуации $\mathrm{S}_{2}$. Данный момент семантики сербского потенциала, в котором исследователи, обратившие внимание на своеобразность соответствующих конструкций в сербоком языке, усматривают проявление инференциальной модальности, см. (Ašić, Dodig 2014), находит аналог в форме французского le temporel conditionnel objectif.

В словенском языке, см. (39), после союза ga с ярко выраженной экспектативной семантической доминантой, которая, кстати, не регистрируется в грамматике словенского языка при описании функций данного союза (Toporiščić 1976: 369-374), следует перфект. Тем самым снимается оппозиция между реальным и ожидаемым на уровне глагольных форм, имеющая место в сербском и хорватском языках.

В македонском языке, см. (40), в данном случае употребляется экспектативная секвентная конструкция, содержащая предлог за и аналитический инфинитив ( $g a+п р е з е н с)$. Такие конструкции напоминают по форме целевые, что дает повод исследователям рассматривать их в качестве псевдоцелевых, однако никакого значения цели - настоящей либо ложной, в них нет. Опираться только на форму при определении типа синтаксической конструкции, по-видимому, не следует, а необходимо исходить из семантко-функционального аспекта предложения.

Таким образом, наличие подытоживающего союза ga в экспектативных конструкциях с секвентной связью, показателем которой является соответствующее временное обстоятельство, представляет собой общую характеристику всех южнославянских языков, кроме болгарского. В других же славянских языках подытоживающая экспектативность нивелируется в предложениях с сочинительными союзами $u / a$ и в бессоюзных предложениях, в которых с помощью лексических средств указывается на секвентную связь между описываемыми ситуациями, представленными ретроспективно - итоговая ситуация следует после ситуации в первой части. Сербский же пример, равно как и хорватский, словенский и македонский переводы, актуализируют проспективный 
момент, так как экспектативность связывается с профилированием впереди стоящего.

Необходимо также отметить, что информанты-носители чешского и словацкого языков, параллельно с приведенными примерами перевода, см. (43-44), предложили и другие - с экспектативным союзом aby, используемым в разных типах предложений для выражения как сочинительной, так и подчинительной связи:

(48) (чеш.) Srbsko se probudilo trojkou Sonji Petrovičové, aby potom, sérii 8-0 během tří a půl minut, družstvo Mariny Maljkovičové znovu vedlo 15-14.

(49) (слов.) Srbsko zobudila trojka Sonje Petrovičovej, aby potom vd’aka sérii ôsmich bodov behom tri a pol minút, družstvo Mariny Maljkovičovej znovu vyhrávalo 15:14.

Данные конструкции информанты считают совершенно приемлемыми в словацком языке. Чешские же лингвисты оговаривают, что такие предложения не совсем соответствуют норме литературного языка, однако типичны для разговорного и публицистического стилей ${ }^{12}$.

Совершенно ясно, что примеры (48-49) напоминают по форме сербоские и хорватские экспектативные конструкции с потенциалом. Частица $b y$, слившись с сочинительным союзом а и перестав быть частью глагольной формы, формирует союз $a b y$, используемый как в сочинительных, так и в подчинительных конструкциях. Поиск в корпусе примеров данного типа не увенчался успехом, что может быть показателем приемлемости, но не распространенности данных конструкций. С другой стороны, часто встречаются примеры антицелевых конструкций с союзом aby, о которых речь пойдет дальше.

\section{2 Выделительная функция союза да в конструкциях с потенциалом}

Как уже было раньше отмечено, конструкии ga+потенциал часто встречаются в сербоском языке в предложениях, описывающих темпоральный ряд ситуаций, каждая из которых является частью одной общей (50). Ситуации сменивают одна другую, а показателем такой смены являются временные обстоятельства, формирующие таксисную цепочку (сначала, затем, наконеи). Особенностью данных конструкций является их яркая экспрессивная окраска, так как часть, присоединяемая союзом

\footnotetext{
${ }^{12} \mathrm{Cp}$. работу о расчлененном союзе $b e z$ toho, aby, в котором он рассматривается в качестве ненормативного заимствования в современном чешском языке. Исследователи считают, что данный союз получил распространение в современном чешском языке под влиянием других славянских языков и, возможно, немецкого языка, см. (Štícha 1997, 79).
} 
$g a$, за которым в сербском языке следует потенциал, описывает ситуацию из ряда вон выходящую, являющуюся логической, но неожиданной развязкой ранее описываемых действий (по-видимому, здесь имеет место

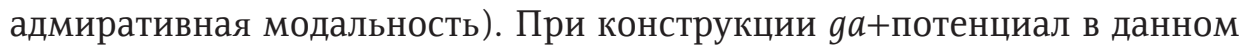
случае обязательно находится обстоятельство времени на крају 'наконец', указывающее на завершение секвентной конструкции, хотя цепь описываемых ситуаций может быть продолжена и после нее. В приводимом примере, см. (61) после кульминационной ситуации, выделенной с помощью конструкции ga+потенциал ( $g a$ бu ce üpoбyguo), несмотря на то, что она отмечена обстоятельством (на крају), указывающим на завершение цепочки ситуаций, следуют две другие ситуации, выраженные глаголами действия (кренуо, ygарио). Таким образом описывается ситуация, состоящая из пяти ситуаций $\left(\mathrm{S}_{1}-\bar{u} о м е р а ~ ш а \overline{u e, ~} \mathrm{~S}_{2}-\right.$ креће ga йрuи, $\mathrm{S}_{3}-\bar{u}$ робуguо би се, $\mathrm{S}_{4}$ кренуо, $\mathrm{S}_{5}-$ уgарио иллавом), при этом ситуация $\mathrm{S}_{3}$ выделяется в сербском языке в качестве кульминационной с помощью конструкции ga+потенциал, см. (50). В данном случае обстоятельство времени на крају 'наконец' указывает на кульминационную, а не на итоговую ситуацию.

(50) (серб.) Овај уснули йас најӣре йочиње gа йомера шайе као gа

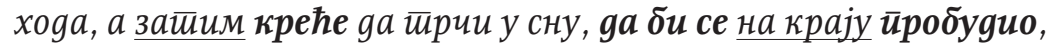
кренуо ка зияу и уgарио у юеїа ілавом!

(51) (хорв.) Ovaj usnuli pas najprije počinje pomicati šape kao da hoda, a zatim kreće trčati u snu da bi se na kraju probudio, krenuo prema zidu i udario u njega glavom!

(52) (словен.) Ta uspavani pes najprej začne stegovati tace, kot da hodi, potem pa začne $v$ spanju teči, da bi se na koncu zbudil, zavil k zidu in udaril vanj z glavo.

(53) (мак.) Овој засйан йес најйрво йочнува gа і̄u йриявижува шейи-

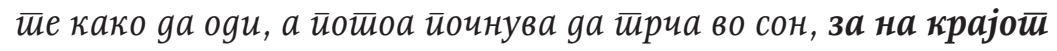

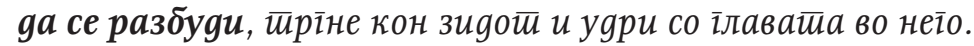

(54) (болг.) Това сънено куче най-найреg зайочва gа gвижи лайийе си, сякаш хоgи, слеg коейо зайочва gа бята, а накрая се събуж-

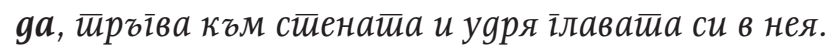

(55) (пол.) Ten śpiacy pies najpierw zaczyna przemieszczać łapy jakby chodził, następnie rusza do biegu w śnie, a chwilę później budzi się, rusza ku ścianie i uderza w nia głowa.

(56) (чеш.) Tento spící pes nejprve hýbal tlapami, jakoby chodil, pak ve snu běžel, a když se na konci probudil, rozběhl se ke zdi a udeřil se o ní hlavou! 
(56a) (чеш.) Tento spící pes začíná nejprve hýbat packami, jako by chodil, a potom začne ve spánku běžet, aby se na konci probudil, rozeběhl se ke zdi a narazil do ní hlavou!

(57) (слов.) Tento spiaci pes najprv začína hýbat'labami ako keby kráčal a potom sa v spánku rozbieha (začína bežat'), na konci sa zobudi, pohne sa $k$ stene a udrie hlavou do nej.

(57a) (слов.) Tento spiaci pes najprv začina hýbat labami ako keby kráčal a potom sa $v$ spánku rozbieha (začína bežat'), aby sa na konci zobudil, pohol sa k stene a udrel hlavou do nej.

(58) (рус.) Эта спящая собака сперва начинает двигать лапами, буgто-бы хоguт, затем бросается бежать во сне, наконеи, просыпается, направляется к стене и бъется в нее головоц̆.

(59) (укр.) Цей пес у сні спочатку починає чеберяти лапами, так ніби хоgить, потім перехоgить на біг, врешті прокияається, налітає на стіну і в gаря в неї головоё.

(60) (бел.) Эты сабака, які заснуў, спачатку пачьнае рухаць ла-

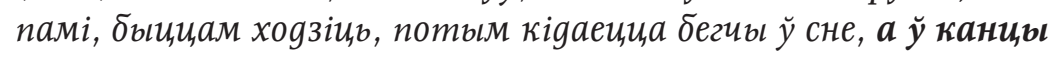
прачьнаещ, а, рушыщ,ь gа си,яны і б'ещ, а у яе галавой!

Как следует из приведенных примеров перевода, см. (50-52),

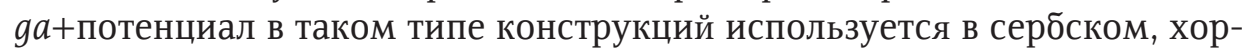
ватском и словенском языках, в македонском используются экспектативные конструкции с предлогом за и аналитическим инфинитивом

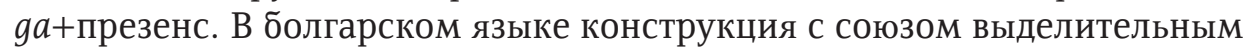
союзом $g a$ в секвентной конструкции отсутствует (54). В западнославянских языках, см. $(55,56,57)$ используется союз а с соответствующим временным обстоятельством, а информанты чешского и словацкого языков снова подтвердили наличие секвентных конструкций с союзом aby в данных языках, см. (56a, 57a). В восточнославянских языках, см. (58-60) союз либо отсутствует либо используется сочинительный союз $a$, при обязательном наличии темпорального конкретизатора, указывающего на вершину секвентной связи (наконеи, врешті, у канцы).

\section{3 Сопоставительная функция союза ga в конструкциях с потенциалом}

При наличии сопоставительных отношений, передаваемых в сербском языке с помощью союза $g a$, за которым следует потенциал, см. (61), во всех славянских языках, кроме хорватского, словенского и македонского, см. (62-64), используется сопоставительный союз $a$, после которого следует обстоятельство времени, указывающее на секвентную связь между ситуациями (вскоре после Этого). 
(61) (серб.) Неко време је раgио као иррофесор у іимназији gа би убрзо затиим био йосйављен за ирофесора филозофије на Филозофском факулиетеиу Универзитетеиа у Скойљу.

(62) (хорв.) Neko vrijeme je radio kao profesor u gimnaziji da bi ga ubrzo zatim postavili za profesora filozofije na Filozofskom fakultetu Sveučilišta u Skoplju.

(63) (словен.) Nekaj časa je delal kot profesor na gimnaziji, da je potem lahko bil $v$ kratkem času nastavljen kot profesor filozofije na Filozofski fakulteti Univerze $v$ Skopju.

(64) (мак.) Некое време рабойеше како ирофесор во іимназија за набрзо йотиоа ga биgе йосйавен за ирофесор йо филозофија на

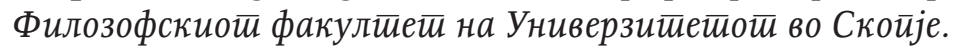

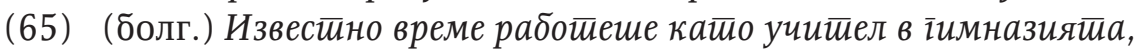
а скоро слеg йова беше назначен за иррофесор йо философия

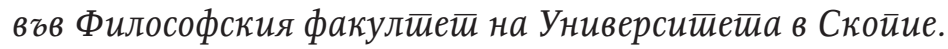

(66) (пол.) Jakiś czas pracował jako nauczyciel w gimnazjum i $\mathbf{w}$ niedługom czasie po tym został powołany na profesora Wydziału Filozoficznego Uniwersytetu $w$ Skopje.

(67) (чеш.) Nějakou dobu pracoval jako profesor na gymnáziu, a brzy poté byl jmenován profesorem filozofie na Filozofické fakultě ve Skopje.

(68) (слов.) Určitý čas pracoval ako profesor na gymnáziu a čoskoro/ o krátky čas bol vymenovaný za profesora filozofie na Filozofickej fakulte Univerzity $v$ Skopje.

(69) (рус.) Некоторое время работал препоgавателем в гимназии, а вскоре после этого его назначили профессором философии на философском факультете Университета в Скопле.

(70) (укр.) Деякий час працегвав виклаgачем у гімназіі, а незабаром після и,вого його призначили на посаgу професора філософії на філософськім факультеті Університету в Скоп'є.

(71) (бел.) Ён пэўны час працаваўнастаунікам у гімназіі, а потым неўзабаве быў прызначаны прафесарам філасофіі на філасофскім факультэие Універсітэта ї. Скоп'е.

Информанты - носители чешского и словацкого языков, и в данном случае предложили параллельные примеры перевода с использованием союза aby:

(72) (чеш.) Nějaký čas pracoval jako profesor na gymnáziu, aby byl brzy poté jmenován profesorem filozofie na Filozofické fakultě Univerzity ve Skopje. 
(73) (слов.) Určitý čas pracoval ako profesor na gymnáziu, aby čoskoro bol vymenovaný za profesora filozofie na Filozofickej fakulte Univerzity $v$ Skopje.

\section{4 Противительная функция союза ga в конструкциях с потенциалом}

Особо выделяем тип конструкций с союзом ga, выполняющим в южнославянских языках противительную функцию, см. (73-76). В сербском и хорватском языках в данном случае также употребляется потенциал, см. (73-74). В качестве семантической доминанты таких предложениях, имеющих адверсативное толкование (an adversative reading Whelpton 2004: 324), можно считать обманутый горизонт ожидания ситуация выходит за рамки ожидаемого, зыждемого на знании о мире:

(74) (серб.) Уложио је тири милиона евра у фабрику и ирријавио заpagy оg осам милиона евра gа би йойом, у јуну, уїасио йроизвоgrty.

(75) (хорв.) Uložio je tri milijuna eura u tvornicu i prijavio zaradu od osam milijuna eura da bi potom, u lipnju, ugasio proizvodnju.

(76) (словен.) $V$ tovarno je vložil tri milijone evrov in prijavil osem milijonov zaslužka, da je potem lahko junija prekinil proizvodnjo.

(77) (мак.) Вложи итри милиони евра во фабрикатиа и иријави за-

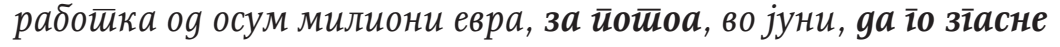
ироизвоgстивойо.

(78) (болг.) Той инвестичра йри милиона Евро във фабрикайа и ойчеше иечалба ой осем милиона Евро, слеg коетио, ирез месеи,

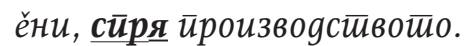

(79) (пол.) Zainwestował 3 mln euro $w$ fabrykę, uzyskał dochód $w$ wysokosci $8 \mathrm{mln}$, a później, w czerwcu zaprzestał produkcji.

(80) (чеш.) Investoval do továrny tři milióny eur a próiznal př́jmy ve výši osm miliónů eur, načež v červnu výrobu zastavil.

(79a) (чеш.) Investoval tři miliony do továrny a priznal výdělek ve výši osm milionů eur, aby poté, $v$ červnu, výrobu ukončil.

(81) (слов.) Vložil tri milióny eur do továrne a oznámil zisk (vo výške) osem miliónov eur, aby potom $v$ júni zrušil výrobu.

(80a) (слов.)Vložil tri milióny eur do továrne a oznámil zisk (vo výške) osem miliónov eur, aby potom, v júni, zrušil výrobu.

(82) (рус.) Вложил в фабрику три миллиона и зарегистрировал gоходы от восьми миллионов, а затем, в ие̌не, закрыл производство.

(83) (укр.) Вклав у фабрику три мільйони та оголосив про прибуток 8 мільйонів євро, а потім, в червні, закрив виробниитво. 
(84) (бел.) Ён уклаў ирры мільёны еура у фабрыку і заявіў/йавеgаміў аб gаховзе ў восем мільёнаў еура, а иойым, у чЭрвені, зачыніў вытивориаси,ь.

Как указано в Whelpton 2004, адверсативные теличные конструкции основаны на том же логическом механизме, как и результирующие. После неуверенности в том, как будет развиваться ситуация в дальнейшем, следует развязка во второй субсеквентной ситуации. В адверсативных конструкциях развязка указывает на неожиданный оборот действий, который не удовлетворяет ожиданиям говорящего ${ }^{13}$. Подобные конструкции, зачастую напоминающие по форме целевые и потому получившие в лингвистике название антицелевых (Белошапкова 1967), хорошо известны в большинстве славянских языков, о чем свидетельствуют соответствующие примеры:

(85) (серб.) Изабраниие селектиора Зорана Терзића зайочеле су йакмичење йоразом оg Кине, gа би йойом наиравиле неверовайну серију йобеgивщи све своје иреостиале ривале (Искра, 06.09, 2015)

(86) (хорв.) Prvo su kod kuće bili bolji od Istre 1961 rezultatom 2:1, da bi potom stradali na gostovanju kod Zagreba (www.lutrija.hr).

(87) (словен.) Gasilci požigali, da bi potem lahko gasili (Murska Sobota, 03.08.2012).

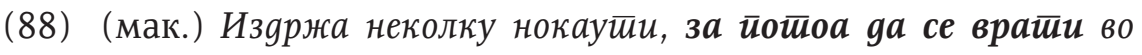
"uīpa" (www.efakt.com.mk).

(89) (болг.) Моника Валериева се йокая, слеg коейо йак се изйийоса їола в мрежатиа. ${ }^{14}$

13 "Viewing the interpretation of the Telic Clauses in this way allows us to see the resolutional and adversative Telic Clauses as sides of the same coin - because the adversative Telic Clauses also resolve our uncertainties about how the main event 'turns out', it simply indicates that the resolution was a negative one, one that does not fulfil our expectations. This is part of the reason why adversative Telic Clauses are easier to formulate. An adversative Telic Clause will be allowed with 'predictable' sequences of events, precisely because it violates the predictability of the sequence" (Whelpton 2004: 324).

14 Просмотр электронного корпуса болгарских примеров показывает, что в болгарских секвентных конструкциях с положительной и негативной экспектативностью преобладает союз слеg коейо и соответствующая глагольная форма, ср.: а) положительная экспектативность: Домусииев обияи журналисти, слеg коейо му се извини (ерісеnter.

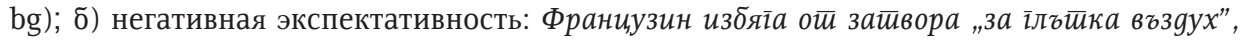
слеg коейо се върна (offnews.bg). Вопреки ценному замечанию профессора Руселины Ницоловой о том, что секвентные конструкции с предлогом за и союзом ga (за ga + глаг. форма) используются в болгарских секвентных конструкциях, в частности, для обозначения негативной экспектативности, нам не удалось отыскать подобные примеры (см. также: Ницолова 1979). 
(90) (пол.) Byłem jego częścia przez niespełna kilka minut, aby potem, kilkaset metrów dalej, zostać zupełnie sam (Radosław Żubrycki, Dzień Zwycięstwa).

(91) (чеш.) V Linkedin zrušili možnost exportu vašich kontaktı̊, aby ji poté vrátili zpět (www.lupa.cz).

(92) (слов.) Vrátil sa, aby čoskoro odcestoval znovu (http://slovniky. korpus.sk).

(93) (рус.) Голубая красавии,а-ель украсила площаgь Терешковой, итоб потом отправиться на свалку! (tvernews.ru/folk).

(94) (укр.) У Вінниці заасфальтували вулиц, щзоб потім знову розкопатu (uavto.vn.ua).

(95) (бел.) Вітаю, а навошта было ўсё аплочвац, каб потым въкigваu,b? (zisser.by)

Если предыдущие типы секвентных конструкций, в которых союз $g a$ выполняет подытоживающую, выделительную и сочинительную функции, можно отнестти к секвентным конструкциям с положительной экспектативностью, то данный тип предложений, с противительным союзом ga, рассматриваем в качестве секвентных конструкций с негативной экспектативностью. Негативная логика развития субсеквентных ситуаций, судя по всему, легче находит выражение в естественных языках с помощью целевых конструкций, чем немаркированная положительная. Этим можно объяснить наличие соответствующего типа конструкций в славянских языках.

\section{Заключение}

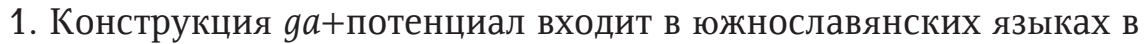
особый тип секвентных предложений, отмеченных в плане выражения особой экспектативной модальности. Распространение данного типа высказываний наблюдается, начиная со второй половины XX века в сербском, хорватском и, частично, словенском языках.

2. Потенциал в подобных конструкциях в сербском, хорватском и словенском языках употребляется в темпоральном значении, сохраняя при этом модальный оттенок условности, результирующий, в сочетании с союзом ga и временными обстоятельствами, экспектативным значением, которое составляет основу для выделения особого вида высказываний - Экспектативных секвентных конструкиий.

3. Да + потенциал в экспектативных секвентных конструкциях используется для выражения результирующих, сопоставительных и противительных отношений между ситуациями, а также для выделения одной субсеквентной ситуации в качестве переломной. 
4. Да+потенциал используется в экспектативных секвентных конструкциях с целью подчеркнутой экспрессивной окраски высказывания. Темпоральная конденсированность данных конструкций делает их удобными для использования в хрониках и исторических описаниях, в которых они лишены экспрессивности.

5. Судя по ответам информаторов, тенденция к расширенному употреблению конструкций с экспектативной модальностью наблюдается в данный момент в македонском, словацком и чешском языках.

6. Во всех славянских языках существуют секвентные конструкции с адверсативными отношениями между частями, указывающими на ситуации. Формальной особенностью таких предложений в серббском и

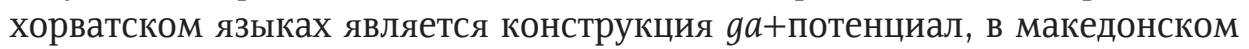
и болгарском языках им соответствует конструкция за ga + презенс. В западнославянских языках аналоги находим в конструкциях с союзом aby + претерит (в чешском и словацком) либо $a b y+$ инфинитив (в польском). В восточнославянских языках после союзов итоб(ъl), щоб, каб, содержащих слившуюся с союзом условную частицу $\delta ы$, следует инфинитив.

7. Способность передавать с помощью наклонений временные значения при актуализации экспектативной модальности можно считать характерной чертой славянских языков. Немаркированная „положительная экспектативность" в последние годы все чаще находит выражение в южнославянских и, частично, западнославянских языках, тогда как отмеченная „негативная экспектативность” выражается во всех славянских языках.

8. Для предложений, известных в славянских языках в качестве псевдоцелевых и антицелевых, предлагаем термин Экспектативные секвентные конструкиии. Данный термин лучшим способом отражает специфику таких предложений с сочинительно-подчинительной связью. В этих конструкциях потенциал с мобильной частицей $\delta ь$, которая может оставаться частью глагольной формы (сербсккий, хорватский, словенский) либо становиться частью союза (чешский, словацкий, польский), указывает на факт ожидаемости осуществленного единичного действия, так как о нем сообщается с позиции ожидания финальной ситуации, подводящей итог предшествующего множества ситуаций, создающего вместе с финальной ситуацией макроситуацию. В серббском, хорватском и, частично, словенском языках значение экспектативности дублирует, кроме потенциала, частица ga, которая вследствие этого может иметь дополнительную экспрессивную нагрузку. 


\section{Использованная литература}

Ашић Тијана. „С оне стране потенцијала”. Научни састанак слависта у Вукове дане 36/1, 2006: 137-151.

Ашић Тијана, Веран Станојевић. „Временске употребе кондиционала у француском и српском језику". [У:] Српски језик, књижевност, уметност, Зборник радова са међународног научног скупа одржаног на Филолошко-уметничком факултету у Крагујевцу. Крагујевац, 2010: 367-379.

Белошапкова Вера А. Сложное предложение в современном русском языке (некоторые вопросы теории). Москва: Просвещение, 1967.

Виноградов Виктор В. Русский язык. Грамматическое учение о слове. Москва Ленинград: УЧПЕДГИЗ, 1947.

Грковић-Мејџор Јасмина. „Развој хипотактичког да у старосрпском језику”. 3борник Матице српске за филологију и лингвистику XLVII/1-2, 2004: 185-205.

Ивић Милка. „О употреби глаголских времена у зависној реченици: презент у

реченици с везником ga". Зборник Матице српске за филологију и лингвистику XIII/1, 1970: 43-54.

Ивић Милка. Лингвистички огледи. Београд: Библиотека XX век, 1995.

Ницолова Руселина. «За интелектуализацията в съвременния български книжовен език». Език и литература 1, 1979: 62-67.

Пипер Предраг. „О кондиционалности у простој реченици”. Јужнословенски филолог LIV, 1998: 41-58.

Пипер Предраг, Иван Клајн. Нормативна граматика српског језика. Нови Сад: Матица српска, 2013.

Потебня Александр, А. Из записок по русской грамматике. Том I-II. Москва: УЧПЕДГИЗ, 1958.

Поповић Људмила. „Функције плусквамперфекта у савременом српском и украјинском језику". Јужнословенски филолог LXVIII, 2012: 113-145.

Станојевић Веран, Тијана Ашић. „О модалним употребама кондиционала у

француском и потенцијала у српском језику", Српски језик XVII, 2012: 65-79.

Стеценко А.Н. Исторический синтаксис русского языка. Москва: Высшая школа, 1972.

Стевановић Михаило. Савремени српскохрватски језик. Граматички системи и књижевнојезичка норма. II Синтакса. Београд: Народна књига, 1974.

Танасић Срето. Синтакса глагола. [У:] М. Ивић (ред.) Синтакса савременога српског језика: Проста реченица. Београд: Институт за српски језик САНУ, Београдска књига, Матица српска, 2005: 345-469.

Ašić Tijana, M. Dodig. „Le conditionnel temporel objectif en français et en serbe”. [In:] Les Études françaises aujourd'hui. Belgrade: Faculté de Philologie de l'Université de Belgrade, 2014: 167-180.

Bauer Jaroslav. Syntactica slavica. Vybrané práce ze slovanské skladby. Brno: Universita J.E.Purkyně, 1972. 
Beekes Robert S.P. Comparative Indo-European Linguistics. An Introduction. Amsterdam, Philadelphia: John Benjamins Publishing Company, 1995.

Dendale P., L.Tasmowski (éds). Le conditionnel en français. Université de Metz, Recherches Linguistiques 25, 2001.

Haillet Pierre Patrick. Le conditionnel en français: une approche polyphonique. Paris: Ophrys, 2002.

Maretić Tomo. „Veznici u slovenskim jezicima”. Rad JAZU 86, 1887: 75-150 (III. Veznik da, 133-150).

Pranjković Ivo. „Vezničko i nevezničko da u hrvatskome jeziku”. Riječki filološki dani 7, 2008: 505-515.

Štícha František. „Ke dvěma méně běžným spojovacím prostředkům v současné češtině (poté, co a bez toho, aby/že): korpusová analýza." Naše řeč 80/2, 1997: 73-80.

Štrkalj Despot Kristina. „Značenje i uporaba suprotnoga veznika da u starohrvatskim tekstovima". Filologija 59, 2012: 173-194.

Toporišič Jože. Slovenska slovnica, Založba obzorja Maribor, 1976.

Vetters C. „Le conditionnel: ultérieur du non-actuel”. P.Dendale, L. Tasmowski (éds), Le conditionnel en français. Université de Metz, Recherches Linguistiques 25, 2001.

Whelpton Matthew. „Elucidation of a telic infinitive”, Linguistics 37, 2001: 313-337.

Људмила Поповић

\author{
ТЕМПОРАЛНА ЗНАЧЕЊА СРПСКОГ ПОТЕНЦИЈАЛА І И ЊИХОВИ \\ ЕКВИВАЛЕНТИ У ДРУГИМ СЛОВЕНСКИМ ЈЕЗИЦИМА
}

\title{
Резиме
}

У раду се разматра специфичан случај темпоралне употребе потенцијала I у српском језику када се он користи за означавање појединачних непонављаних ситуација. Анализа реченица са таквим потенцијалом у српском језику у поређењу са одговарајућим синтаксичких конструкцијама у другим словенским језицима показује да потенцијал I у комбинацији са везником ga и темпоралном одредбом формира посебан тип сложене реченице са напоредно-зависним

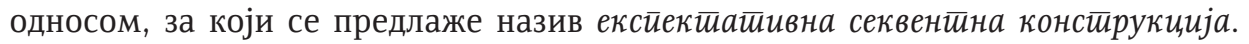
Особеност експектативне секвентне конструкције састоји се у томе да она обавезно поседује два дела, или више њих, у којима су представљене субсеквентне ситуације једне опште ситуације. Притом субсеквентна ситуација $\mathrm{S}_{2}$ представља логички завршетак ситуације $S_{1}$. Уколико ситуација $S_{2}$ представља очекивани наставак развоја ситуације $S_{1}$, ради се о тзв. позитивној експектативности, која 
се манифестује кроз употребу конструкције ga+потенцијал. Од свих словенских језика такву конструкцију бележимо само у српском и хрватском језику. Уколико је резултатирајућа ситуација $\mathrm{S}_{2}$ у супротности са хоризонтом очекивања који одређује ситуација $S_{1}$, јавља се обележена негативна експектативност која се изражава тзв. антициљним или псеудоциљним реченицама у свим словенским језицима.

Кљуине речи: експектативна конструкција, потенцијал, везник ga, антициљне реченице, секвентни однос, словенски језици 